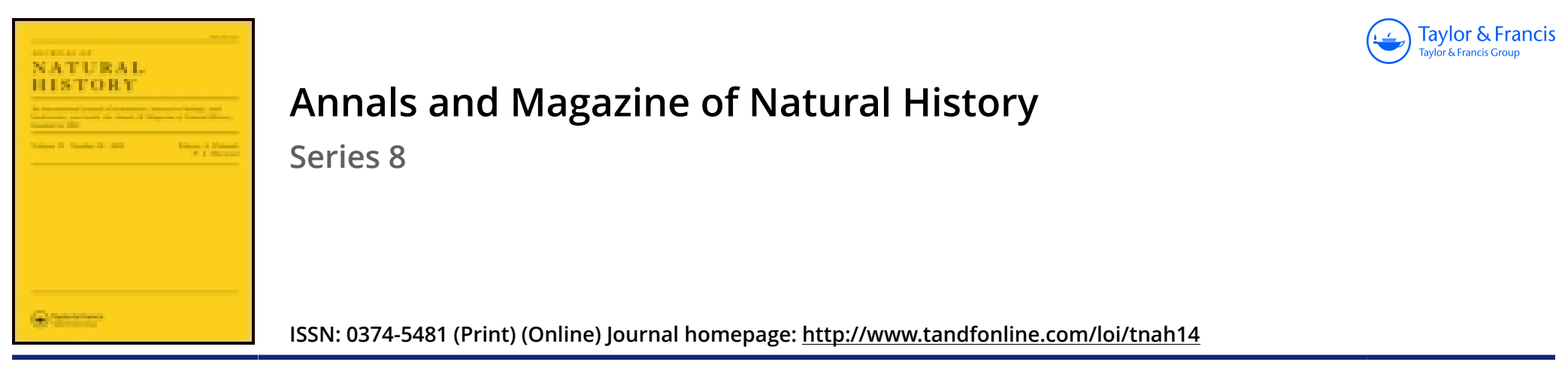

\title{
LV.-Some new Lepidoptera from Siam and Africa
}

\section{Lord Rothschild F.R.S. Ph.D.}

To cite this article: Lord Rothschild F.R.S. Ph.D. (1916) LV.-Some new Lepidoptera from Siam and Africa, Annals and Magazine of Natural History, 17:102, 474-476, DOI: $\underline{10.1080 / 00222931608693813}$

To link to this article: http://dx.doi.org/10.1080/00222931608693813

曲 Published online: 11 Sep 2009.

Submit your article to this journal 전

LII Article views: 2

Q View related articles $\sqsubset$ 
on each side of the smooth median line, constricted and transversely depressed before the base, the tive setigurous marginal tubercles well developed. Elytra moderately long, subparallel in their basal half and arcuately narrowed thence to the apex, the post-basal depression deep; with interrupted rows of scattered punctures, which become very fine towards the apex, the scutellar region sometimes with additional scattered punctures, the interstices smooth and flat.

Length $3 \frac{1}{2}-4 \mathrm{~mm}$. ( $\sigma^{\star} q$.)

Hab. Brazrt, Rio de Janeiro, Pernambuco (Fry).

Described from three specinens. A tourth example (one of the two from Pemambuco), somewhat inmature, with a broader head and prothorax, larger eyes, and more closely punctate elytra, seems to belong to the same species. The elytral markings are not unike those of the variable $P$. maculatzs, Champ., from Central America, which has the antenual joi:ts 9 and 10 longer and stouter than those preceding, and the elytra regularly striato-punctate. $P$. vittalus, Reitt., is said to havo the elytra ferruginous, with the snture and sides broadly nigro-piceous, and it cannot therefore be conspecific with the present species.

\section{LV.-Some new Lepidoptera from Siam and Africa. By Lord Rothschild, F.R.S., Ph.D.}

The two Siamese Amathusido were collected by Mr. Godfrey of Bangkok, who has presented the Stichophthalma to the British Museun.

\section{RhOPALOCERA.}

Stichouhthalma godfreyi, sp. n. $\mathrm{Hew}$.

Upper surface.-Head brownish rufous; antennæ rufous; thorax and abdomen greyish brown, abdomen washed with blackish. Fore wing: basal halt greenish steel-blue washed with olive-brown on costal area and from the base distad; outer half greenish white or white tinged with Nile-green; terminal band, apex, and subrnarginal row of large excised patches black-brown washed with steel-blue; a post.nedian band of dark greenish steel-blue chevrons joined into a chainlike band. Hind wing similar, only the submarginal band of excised patches is replaced by a second row of chevrons and the white ground of the outer half of the wing is 
strongly suffused with greenish lavender-blue. Underside very similar to that of cambodia, but much darker; all the lines and other markings much sharper and the double submarginal bands deep brown.

Length of fore wing $72 \mathrm{~mm}$., expanse $151 \mathrm{~min}$.

Hab. Siam (near Kambusi, 8.5. 1914).

Thauria lathyi siamensis, subsp. n.

In Seitz's 'Macrolepidoptera of the World,' Herr Fruhstorter has treated the tour forms of Thauria, known to him, as SUBSPECIES of one species, Thauria aliris, Westw.-at the same time remarking that his luthyi was almost worthy of specitic rank, as it lacked the conspicuous tuft of androconial hairs in the cell of the hind wings.

'The 'l'ring Museum possesses, how cver, from the Tenasserim Valley and Toungoo, Burmah, both typical $7 \%$. a. p'seudaliris, with very narrow, yellow, oblique band on the fore wings and large cellular androconial tuft on hind wings, and also a form of lxthyi with large whitish-cream oblique bands on fore wing and no cellular androconia on hind wing (described below). From Perak there are also in the Tring Museum a large serirs ( $9 \delta^{*} \delta, 3 q q$ ) of a. pseudaliris and $2 q$ of the form of lathyi described below. This proves that lathyi occurs side by side with a. pseudaliris and that it is a quite distinct species.

o. Differs from l. lathyi in being much smaller, the basal onc-third of fore wing is suffused with much deeper, more maroon rufous, and the oblique pale band of fore wing is considerably wider and pure white.

Length of fore wing $50 \mathrm{~mm}$., expanse $106 \mathrm{~mm}$. : l. siamensis.

Lengtl of fore wing $53 \mathrm{~mm}$., expanse $112 \mathrm{~mm}$. : l. luthyi. Hab. Siam (Hoopbok, 26.4. 1914).

Thauria latiyi amplifuscia, subsp. $\mathrm{n}$.

$\delta q$. Differs trom l. lathyi by its larger size and by the oblique pale band of the fore wing being quite twice as wide at vein 4.

Wiilth of oblique band (I. lathyi): $86 \mathrm{~min} .$, $q 11 \mathrm{~mm}$.

Wilth of oblique band (l. amplifuscia) : $\delta 16 \mathrm{~mm}$., क $17 \mathrm{~mm}$.

Length of fore wing (l. lathyi) : $\$ 53 \mathrm{~mm}$., $\$ 61 \mathrm{~mm}$.

Length of fore wing (l. amplifascia) : क $60 \mathrm{~mm}$., \& $67 \mathrm{~mm}$.

Expanse: l. lathyi, o $112 \mathrm{~mm}$., \& $128 \mathrm{~mm}$; l. amplijascia, of $126 \mathrm{~mm} .$, \& $140 \mathrm{~mm}$. 
Hab. Toungoo, Burmah (type); Shan States ; Tenasserim Valley; Perak; (2 $\delta \delta^{\circ}, 6 \% q$ in Tring Museum).

(Th. aliris intermedia, Crowley, has wider oblique light bands on the fore wing in the $q$, and very conspicuous cellular androconial tufts in the $\delta$; it occurs in Toungoo, Burmah, alongside of Th. lathyi amplifascia.)

\section{HETEROCERA.}

\section{Lymantriidæ.}

Ogoa oberthueri, Rothsch., sp. n.

$\delta$. This is undoubtedly a giant, as the largest species described up to now only expands $72 \mathrm{~mm}$.

Antennæ heavily pectinated, shaft black-brown, pectinations deep black; head, thorax, and first two segments of abdomen dirty cream-white, rest of abdomen cinnamon-buff.

Fore and hind wings, above and below, semivitreous buffish cinnamon, outer half teebly powdered with sooty scales; on fore wing an angled median band and on hind wing a postmedian convex band of more densely placed sooty scales, some 4 millimetres wide.

Length of fore wing $62.5 \mathrm{~mm}$., expanse $135 \mathrm{~mm}$.

Hab. Grande Comore (named in honour of Mr. Charles Oberthür, who did so much for the exploration of the Comoro Islands).

\section{Ogoa neavei, sp. $\mathbf{n}$.}

ð. Legs black; antennæ deep black; head and thorax deep orange; abdomen black, three basal and the anal seg.nent orange.

Fore wing dark smoky grey ; median and outer quarter of costal area orange, intranervular spaces in basal two-fifths suffused with orange, in the outer three-fifths the intranervular spaces are only somewhat washed with orange, more strongly towards termen; an oval, ill-defined, dull orange patch below median vein between veins 2 and 3 . Hind wings orange, a sooty-black patch on upper discocellular veinlet, vein in cell sooty black, a submarginal sooty-black sinuate band beyond which the nervures to termen are also black, and the interspaces sprinkled with black scales.

Several other of o show a second oval patch between veins 3 and 4 . $\quad$ similar, but paler and duller.

Length of fore wing $44 \mathrm{~mm}$., expanse $95 \mathrm{~mm}$.

Hab. Mt. Mlanje, Nyassaland, Dec. 1913 ( $A$. S. Neave coll.; Brit. Mus.). 